\title{
DEVISING A DEVELOPMENTAL TEST OF AUDITORY PERCEPTION: PROBLEMS AND PROSPECTS
}

\author{
Arnold Abramovit7, M.Sc. (Psychol.) \\ Senior Lecturer, Department of Psychology, University of Cape Town
}

When, about six years ago, I embarked on the development of a psychological instrument that would evaluate certain complex auditory abilities in both normal and handicapped children, I knew I was undertaking an important, difficult, but not impossible, task. I still consider the task to be both important and difficult. But now, older, wiser and sadder, I no longer believe that a single individual, with a uni-disciplinary background, can cope with what such an undertaking entails. We will one day have a developmental test, or series of tests, that will provide genuine assistance in the multi-faceted problem of the assessment of auditory perception, but it will require the pooled resources of a multi-disciplinary team of workers-psychologists, linguists, phoneticians, audiologists, otologists, paediatricians, speech therapists, speech trainers, educationists, musicians, neurologists, physicists, sound engineers, statisticians, and other specialists impossible to specify in advance. Why should this be? We have, after all, a developmental test of visual perception devised largely by a single person $\left(\right.$ Frostig ${ }^{2}$ ). Why should auditory perception prove to be such a different kettle of fish? What work I have done, of which some account is given in this paper, leads me irresistibly to the conclusion that the reception, processing and interpretation of acoustic signals constitute some of the most elusive and complex phenomena to attempt to examine, gauge and measure.

To a certain extent, this is due to the transient, ephemeral nature of sound itself. You cannot pin it down or "freeze" it in the way that you can, through drawings and pictures, capture and secure certain aspects of visual perception. So, correspondingly, you will find very few items in children's intelligence tests that are directly concerned with the basic skills related to auditory perception as such. The only exceptions $l$ can think of are tests of auditory memory span, involving digits, words and sentences, which invoke a minimum of higher symbolic processes. Psychologists have, in general, been quite shy about the developmental processes governing auditory perception, and have done very little in the gathering of relevant normative data. I am aware that various tests of auditory perception are used by speech and hearing pathologists, but the ones $I$ have come across fail to meet certain minimum criteria which a general test of auditory abilities applicable 
smile, or the other in which his demeanour is one of disappointment. Three practice items are included.

D. Discrimination of the basic psychological parameters of formal tonal patterns, viz. pitch, loudness, duration and interval. Twenty-four pairs of tone combinations form the basis of this test. Three notes are used, C, D and E (above Middle C) recorded from the outputs of a series of sine-wave oscillators. The tonal patterns are random combinations of these three notes, using one of two levels of intensity and one of two periods of duration for each of the notes, and one of two intervals between the notes. Six practice items are presented in which the different types of "error" are emphasized by the examiner whistling or singing the "tunes". Three drawings are again used to assist in communicating the instructions. The first drawing shows a man and a boy each playing a bugle. The second and third drawings show the man respectively pleased and disappointed. Their difficulty is increased (a) by increasing the number of notes per pattern (from three to five), (b) by introducing "errors" with respect to parameters which are more difficult to discriminate, e.g. intensity and duration, and (c) by decreasing the number (from four to one) of "errors" per pair.

\section{Subjects}

This test was applied to 205 children, aged five to ten years, drawn from a middle-class, White, primary school population (the "nonhandicapped" sample), and to 232 White children with a variety of handicaps and difficulties (the "handicapped" sample). The latter included children from schools for (a) the deaf, (b) the hard-of-hearing, (c) the cerebral-palsied, (d) the retarded, (e) the blind, and (f) children referred to the U.C.T. Child Guidance Clinic for various emotional, behavioural and scholastic problems. In addition to the test of auditory abilities described above, these children were assessed on the National Bureau Group Test (either 5-6, 7-8 or 8-11 years, amended for individual administration), as well as the Goodenough Draw-a-Man Test and the Digit-Span Test of the WISC.

\section{Scoring-system}

Finding a reliable scoring-system for the auditory abilities proved to be the major stumbling-block. Relying on the test as a purely objective multiple-choice instrument, it turned out that for each of the six agegroups, 5 years to 10 years, only the second sub-test, Auditory FigureGround Discrimination, possessed adequate Split-half reliabilities. It was hoped that a scoring-system which, took into account aspects of the child's responses other than picture-matching would result in higher reliabilities. This was found to be quite feasible for the older, more intelligent child, where verbal and other responses to the sounds could be quantitatively scored or rated. It was, however, seldom possible to elicit these kinds of reactions from children of lower mental ages or 
children with communication handicaps. In the case of the first subtest, Recognition of Environmental Sounds, it was found that a threepoint scale $(0,1,2)$ instead of a right-wrong criterion (1 or 0 ) resulted in somewhat larger odd-even correlation coefficients. The relevant quantitative data are tabulated elsewhere (Abramovitz ${ }^{1}$ ).

\section{RESULTS}

The reliabilities for Recognition of Environmental Sounds were generally disappointing, especially at the 5-year and 10-year levels, but the corresponding Standard Errors of Measurement, which Roberts ${ }^{3}$ regards as more important than reliabilities for multiple-choice tests, were within reasonable limits. The reliabilities and Standard Errors of Measurement for Auditory Figure-Ground were uniformly good. It was decided, therefore, to proceed with the "handicapped" sample using these two sub-tests only-which could be administered in one session of 15-20 minutes.

The next step was to establish the ability of these tests to discriminate between adjacent age groups. Calculations of two-tailed levels of significance showed that the test in this form was not always suitable for accurate inter-age-level differentiations. This was not, however, the only objective of the study. Having established the presence of a reasonably lawful developmental gradient, it was considered feasible to compile tentative norms for successive age levels. These were drawn up as quotient scores (via the calculation of percentile ranks), with 100 as the mean and 15 as the standard deviation. The quotient scores for the auditory tests were all reasonably close to those of the other ability tests, and it could be justifiably assumed that the auditory tests discriminated between different mental age levels to about the same degree as they did between corresponding chronological age levels.

Turning now to the "handicapped" groups, the first results to be considered are those for 19 subjects from a school for cerebral-palsied children, whose average age was about 10 years. Although the average of their overall auditory quotients was not significantly different from that of their WISC quotients (about 80), the remarkable finding here was that mean Figure-Ground quotients were significantly lower $(\mathrm{P}=0,02)$ than Single-Sound quotients (75 vs. 91). These subjects were not selected on the basis of any prior knowledge of their general perceptual abilities and in fact included children with purely motor handicaps. Nevertheless, many children reported only one of each of the 20 double and triple sounds, a phenomenon which almost constituted a kind of negative auditory hallucination. This occurred in spite of the examiner's asking, or indicating by mime, very emphatically, for a more attentive reaction after each such failure. This was quite a dramatic phenomenon, and many of the trainers who were present during these sessions were clearly taken aback by the unexpected performance of these children. They were about average when it came to identifying single environmental sounds, yet many were apparently unable to 
establish the simultaneous presence of two sounds, each of which they had no difficulty with on its own.

Since these results pointed to more ominously defective auditory processes than seemed likely; it was decided to test the hypothesis that they were simply due to perseveration arising from the previous presentation of 24 single sounds. Sixteen of these subjects were retested four weeks later using slightly different instructions when presenting the first three double sounds (but in no other respect). If the subject failed to report both sounds, the examiner asked, "And what else did you hear?" (No extra points were awarded for correct responses arising from the new instruction on these three items). If this still failed to produce the correct response, the examiner would point out the two sounds concerned. After the third item no further help was given and the test was administered as before. The result of this simple change of instruction was quite as astonishing as the previous phenomenon. The average Figure-Ground quotients jumped from 78 to $99(P=0,001)$. The average Single Sound quotients rose, non-significantly, from 92 to 97 . The perseveration hypothesis was thus amply substantiated.

This finding should not, however, be taken as having no bearing on these subjects' auditory abilities. Many, if not most, real-life auditory situations do not allow for a "second chance". The auditory perseverator is a handicapped listener, and his problem should not be minimized.

After this experience, whenever there was a query about possible perseveration, the Figure-Ground test was always re-presented in toto, using the amended instructions described.

The next group of subjects were taken from a home for retarded children, but their age-range extended from 7 years 6 months to 29 years 5 months, with a mean of 18 years 6 months. Their IQ's were not available, but were probably in the 25-60 region. Each of the 45 children who could be tested (children below a mental age of about $3 \frac{1}{2}$ years could not) were also given a Goodenough Draw-a-Man test. The results (using scores obtained from the amended instructions) showed (1) that mean Figure-Ground discrimination was significantly poorer $(P=0,001)$ than Single-Sound identification (61 vs. 72 months, test-age), (2) that the overall average auditory test-age was not significantly different from that for the Goodenough Draw-a-Man test (66 vs. 68 months, test-age), and (3) that there were moderately high $(0,45$ to 0,64$)$ positive correlations between these tests.

Sixteen children from a school for the deaf formed the next group of handicapped subjects. They were all tested (in the first instance) with hearing-aids fitted and adjusted, in the ordinary open-field manner adopted for hearing children. Their average scores for Single-Sounds and Figure-Ground were almost identical, with a quotient-score of about 50. The question arose whether their hearing-aids were of real assistance to these children in this particular situation. It was hypothesized that, with the tape-recorder volume turned up to a subjectively comfortable listening level, and their hearing-aids removed, scores 
obtained would be higher because of the elimination of one source of distortion in the reproducing chain. Ten of these children were re-tested a week later and a comparison of the results showed that highly significant increases occurred. Although one could not be sure to what extent a practice effect contributed towards this improvement, a comparison with the brain-injured group is instructive. In the latter case the improvement in the Single-Sound scores was only about $6 \%$ and was not significant, whereas with the deaf group the improvement was about $17 \%$ and highly significant $(\mathrm{P}=0,001)$. The corresponding Figure-Ground improvements were about $14 \frac{1}{2} \%(\mathrm{P}=0,001)$. In the absence of an adequate experimental design, inferences can only be tentative, but might be framed as follows: (a) Deaf children do not ordinarily show the kind of perseveration that is seen with cerebralpalsied and retarded children, and (b) some deaf children are fitted with hearing-aids which amplify auditory stimuli at the cost of a significant degree of distortion. (It was a moving experience to find a profoundly deaf child with her unamplified ear glued to the loudspeaker coming up with scores that were at least as good as hearing children of her age-level.)

The next group consisted of 16 children taken from a school for the hard-of-hearing. Of these, six were randomly chosen for testing without their hearing aids. The ten hearing-aided children had mean Single-Sound and Figure-Ground quotients of 71 and 74 respectively, while the six unaided children had quotients of 76 and 83 respectively, a positive difference of $7 \%$ and $12 \%$ respectively. This shows roughly the same trend as the deaf sample, but not as markedly. The inference again is that peripheral hearing loss does not show the same pattern as organicity. (One boy, diagnosed as very severely "dyslexic", sailed through Figure-Ground without a single error-and without his aid. One couldn't help wondering where his real problem lay.)

Next was a sample of 58 children from two primary schools, whose principals queried their general school progress. In one case (a school serving parents in the professional and higher managerial class) there was a significantly lower mean Figure-Ground quotient (86) than Intelligence Quotient (109) $(P=0,05)$. In the other case, however, (a school serving parents of the artisan and lower clerical class) there was no such difference ( 97 in each case). Teachers of the children from these two schools were asked to assess each child's reading and spelling achievement on a five-point scale : excellent-good-fair-rather weak - very poor. Nineteen children were rated as "rather weak" or "very poor" on either or both reading and spelling. The average Single-Sound quotient and Intelligence Quotient were each 95, but the average Figure-Ground quotient was down to $81,5(\mathrm{P}=0,06)$. It was difficult to resist making the tentative inference of handicapped listening ability, due at least in part to some kind of auditory perseveration.

The results for an unselected group of 32 children referred to the U.C.T. Child Guidance Clinic for a variety of behavioural, emotional 
and scholastic problems showed that although the mean Figure-Ground quotient (92) was not much lower than the IQ (94), it was significantly $(P=0,05)$ lower than the mean Single-Sounds quotient (102). Fifteen children from this group were selected on the basis of a reading and/or spelling retardation of at least 12 months. Although the mean FigureGround quotient (95) was lower than the mean Single-Sounds quotient (100), the difference was not significant. This finding does not correspond with that for a similar group taken from the two schools mentioned above. Without further data and analysis there is no way of resolving the anomaly.

Finally, a group of 21 blind children were compared with an equal number of roughly equated sighted children (mean age for blind about 10 years, for sighted about 9 years, both groups of average intelligence). The test could obviously not be administered in the usual way, and instead of presenting four drawings, the examiner asked the subject (in both the blind and sighted groups) to choose from four spoken alternatives, after each auditory stimulus. Mean quotient scores for the auditory tests were in all cases higher for the blind children. In the case of Single-Sounds this difference (106 vs. 99) was not statistically significant, but for Figure-Ground the difference (108 vs. 77) was significant at the 0,001 level. This result does not necessarily signify that blind children have superior auditory perceptual abilities of the kind tapped by this test, but rather that their retention of the recorded material and (in particular) the spoken alternatives was better than that of the sighted children, due to the intensive auditory training received at their institution - a great deal of which was being obtained through the medium of the tape-recorder. This last statement could be put the other way around, of course. The results might be seen as an indication of the comparative lack of training in listening skills which normal school-going children receive, and a corresponding bias (after a certain age-level) in favour of visual modes*of information-gathering.

As with most individually-administered instruments, a great deal of information which eluded quantitative scoring could be gleaned about the responses of the subject to the test situation in general and the auditory stimuli in particular. There were apparently great individual differences in emotional and motivational reactions-from delight to boredom to aversion-as judged by facial expression gesture, posture, spontaneous vocalizations, verbalizations, and so on. The first subtest, Recognition of Environmental Sounds, seemed to elicit a pattern which might be called "alertness to the (non-linguistic) auditory environment", involving an ability to retain a sort of auditory after-image while the decision or discrimination between the four alternatives was made. This presumably took place by matching the auditory after-image with each of the auditory images aroused by the pictures, but perhaps not without a certain amount of deductive reasoning in some cases. The child with low scores here displays a variety of reactions, from an overconfident belief that he recognizes the sound before seeing the pictures 
and an inability to decentrate (in the Piagetian sense) when necessary: to a blank reaction $a b$ initio and then either a "don't know" response (guessing was not encouraged); or a choice by the process of elimination; or a response-set for one of the four illustrations (the bottom left-hand drawing seemed to be a favourite for many handicapped children). One was often inclined to make the diagnosis of "auditory agnosia" when quotient scores on this test were very low, but this would of course be extremely rash in the absence of a great deal-of supporting dąta.

The Figure-Ground test provided the most compelling example of deviant auditory behaviour, namely the perseveration already referred to. In its extreme form, it occurred only three times in the 205 nonhandicapped sample. The term "negative auditory hallucination" has already been mentioned in this connection, but the change in response as a result of slightly altered conditions of administration showed how inappropriate such an interpretation might be. This auditory perseveration occurred at all age-levels in the transition from double to triple sounds (for which no additional instructions were given with any of the groups). The test seems to reveal firstly the ability to focus on one of the multiple sounds at a time, i.e. perceiving it as "figure", while the other sound or sounds rapidly and in turn are relegated to "ground". This inability seemed likely in many cases to be part of a general personality factor, a sort of submissive, deferential reaction to the examiner in particular, and perhaps to the social environment in general. Some of these children seemed even prepared to doubt the validity of their own experiences if they thought they were expected to make self-reports of a certain class and no other.

A child's reaction to the test as a whole often gave the examiner a strong impression of "listening ability", or the lack of it, and this did not necessarily correspond to his score on the test, or to his intelligence results, or to the audiometrist's report of his hearing acuity. With regard to the latter issue, when a child of at least average intelligence was referred for scholastic, behavioural or emotional problems and scored below a quotient of 85 on the auditory test as a whole, audiometry was recommended and in most cases carried out. The resulting audiograms were mostly within normal limits but at least 6 children were found to have slight $(15-25 \mathrm{~dB})$ conductive losses and at least 3 children were found to have moderate $(25-35 \mathrm{~dB})$ conductive losses, in at least one ear. Correspondingly, some of the children from the school for the hard-of-hearing (and even one from school for the deaf) had average or above-average auditory quotients.

In spite of some of the interesting and useful group results obtained, the test as used was a truncated and relatively unrefined instrument, not really suitable for reliable individual assessment. This being so, what could be done to improve the reliability and validity of the two sub-tests used, and what sub-tests could be devised to replace the abandoned Speech Sound Discrimination and Tonal Pattern Discrimination tests? I think these are questions for our imaginary multi- 
disciplinary team to thrash out, but some of my own thoughts may not be out of place.

As to the first question, I think the basic notions behind the two sub-tests used are reasonably sound. What is needed is to mount a full-scale programme in which a much larger number of subjects of diverse backgrounds serve in the pilot runs and finally in the standardization sample. Using a larger number and variety of sounds and matching pictures, those which don't contribute to the reliability and validity of the test can be eliminated.

With regard to the second question, I must first of all ruefully admit to wanting to leave speech sound discrimination to the exclusive jurisdiction of speech and hearing specialists. This whole territory is a veritable minefield for the innocent psychologist. Consider, for example, the almost impossible task of constructing a comprehensive test which, in addition to meeting the criteria already alluded to, will not favour one linguistic community over another.

In connection with tonal pattern recognition, ${ }^{\circ} \mathrm{I}$ now consider that the fourth criterion is misconceived, and that for this particular kind of skill, at least, one should not try to isolate the auditory modality from the visual and the kinaesthetic. All perception, as Taylor's ${ }^{4}$ compelling work reminds us, is intersensory, and we specifically need tests of audiovisual, visuo-auditory and audiomotor skills. Such tests exist of course. How suitable they are for the purposes of constructing an all-embracing developmental test of auditory perception remains an issue for debate and research.

Finally, a technical point, but a very important one, which applies to every kind of auditory test-stimulus. Convenient as the ordinary taperecorder undoubtedly is (compared, say, to disc recordings), it has an inherent disadvantage. You cannot re-present a stimulus without a good deal of fuss and delay. What is needed is a tape-player which allows the examiner to re-administer a given item as often as he wishes with no waste of time. There is at least one such instrument on the market that I know of, namely the Bell \& Howell "Language Master" (probably familiar to most readers of this Journal) in which cards of varying dimensions carrying the magnetic tape are conveniently fed into the machine by hand. These cards could also have, behind them, the multiple-choice pictures, and the subject's score would depend, in 'part, on the number of times the item had to be presented before the correct picture was pointed to. There is an electronic-acoustic problem to be solved, namely altering the recording-head and circuit to provide an adequate frequency response, say $40-15 \mathrm{KHz} \pm 3 \mathrm{~dB}$.

\section{SUMMARY}

It is certain that many children whose auditory perception is queried by audiologists, speech therapists, educationists and psychologists elude the diagnostic screens presently available in each of these disciplines. 
The need for a qualitative and quantitative psychological assessment of the child's auditory abilities and disabilities led to the development of a test which was intended to evaluate the following functions: (a) Recognition of environmental sounds, (b) Auditory figure-ground discrimination, (c) Speech-sound discrimination (phonemic and intonational) and (d) . Tonal pattern discrimination (pitch, loudness, duration and interval). It was not intended to investigate threshold phenomena as such but rather to supplement and complement pure-tone and speech audiometry. The test was applied to 205 children, aged five to ten years, drawn from a normal school population, and 232 children with difficulties and handicaps varying both in degree and kind.

Only the first two sub-tests were found to be clinically and experimentally viable, and data for the curtailed test are presented. The following results are noteworthy:

(1) The test measures functions which are positively related to both age and intelligence.

(2) Brain-injured, retarded and emotionally disturbed children generally test low on auditory figure-ground discrimination; this vulnerability is most likely due to perseveration.

(3) Previously unsuspected peripheral hearing losses may sometimes be detected by the use of the test. On the other hand, some children said to have high degrees of hearing loss test at or above their age-level.

(4) Many deaf and hard-of-hearing children test higher without their hearing-aids; this is probably due to amplification being achieved at the cost of distortion.

(5) Children of average intelligence with reading and/or spelling diffculties often test low on auditory figure-ground discrimination.

(6) Blind children who have received auditory training are equal to sighted children in recognition of environmental sounds, but superior in auditory figure-ground discrimination. This does not, however, necessarily signify superior auditory perception as such on the part of the blind.

In general it is concluded that the development of tests of auditory perception could add significantly to the psycho-educational assessment of both "normal" and handicapped children.

\section{OPSOMMING}

Daar kan met sekerheid aanvaar word dat baie kinders van wie die ouditiewe waarnemingsvermoë betwyfel word deur oudioloë, spraakterapeute, opvoedkundiges en sielkundiges, die diagnostiese toetse vandag tot hul beskikking ontglip.

Die behoefte wat daar bestaan vir 'n kwalitatiewe en kwantitatiewe sielkundige bepaling van 'n kind se ouditiewe vermoë en onvermoë het gelei tot die ontwikkeling van 'n toets wat gemik is op die evaluasie van die volgende funksies:

1. Herkenning van omgewingsgeluide.

2. Ouditiewe figuur-grond onderskeiding. 
3. Spraakklank diskriminasie (foneem- sowel as intonasie-onderskeiding), en

4.: Tonale patroondiskriminasie (toonhoogte, luidheid, duur, en interval).

$\therefore$ Dit was nie die bedoeling om drempelverskynsels te ondersoek nie, maar slegs om 'n toets te ontwikkel wat ter aanvulling kan dien by suiwertoon- en spraakoudiometrie.

Die toets is uitgevoer op 205 kinders, met ouderdomme wat wissel van 5 tot 10 jaar, getrek uit 'n bevolking van normale skoolkinders en op 232 kinders met afwykings en belemmerings wat verskil betreffende die tipe afwyking asook die erns van die probleem.

Slegs die eerste twee subtoetse is klinies en eksperimenteel uitvoerbaar en data vir die verkorte toets word uiteen gesit.

Die volgende resultate kan beslis op gelet word:

1. Die toets meet funksies wat in verhouding staan tot beide ouderdom en intelligensie.

2. Breinbeskadigde, vertraagde en emosioneel-versteurde kinders gee 'n lae telling by toetsing van ouditiewe figuur-grond onderskeiding; hierdie kwetsbaarheid is moontlik toe te skryf aan perseverasie.

3. 'n Perifere gehoorverlies voorheen onopgemerk, kan soms met behulp van hierdie toets opgespoor word. Aan die anderkant weer toets sommige kinders van wie gesê is dat hul hoë grade van gehoorverlies het, by of bokant hul ouderdomspeile.

4. Baie dowe en hardhorende kinders toets hoër sonder hul gehoor apparate; dit is moontlik tewyte aan versterking verkry ten koste van distorsie.

5. Kinders van gemiddelde intelligensie met lees- en/of spelprobleme gee dikwels 'n lae telling by toetsing van ouditiewe figuur-grond onderskeiding.

6. Blinde kinders wat reeds gehooropleiding ontvang het, behaal dieselfde resultate as siende kinders wat herkenning van omgewingsgeluide betref, maar is superieur wat ouditiewe figuur-grond onderskeiding betref; hierdie resultate dui nie noodwendig op superieure ouditiewe persepsie by die blinde nie.

Daar word ten slotte beweer dat die ontwikkeling van ouditiewe persepsietoetse baie kan bydra tot die psigo-opvoedkundige toetsing van beide „normale” en gestremde kinders.

\section{REFERENCES}

I. Abramovitz, A. (1967): Auditory perception and the handicapped child. Paper presented at the XVIII Annual Congress of the S.A. Psychological Association, Cape Town, September 1967. (Unpublished mimeograph).

2. Frostig, M. et al. (1964): Developmental test of visual perception. Perceptual and Motor Skills, 19, 463-499.

3. Roberts, A. D. H. (1962): The maximum reliability of a multiple-choice test. Psychologia Africana, 9, 286-293.

4. Taylor, J. G. (1962): The behavioural basis of perception. Yale University Press, New Haven, Connecticut. 